\title{
Front Matter: Volume 6403
}

, "Front Matter: Volume 6403," Proc. SPIE 6403, Laser-Induced Damage in Optical Materials: 2006, 640301 (23 January 2007); doi: 10.1117/12.725203 Materials for High Power Lasers, 2006, Boulder, Colorado, United States 


\section{LASER-INDUCED DAMAGE IN OPTICAL MATERIALS: 2006}

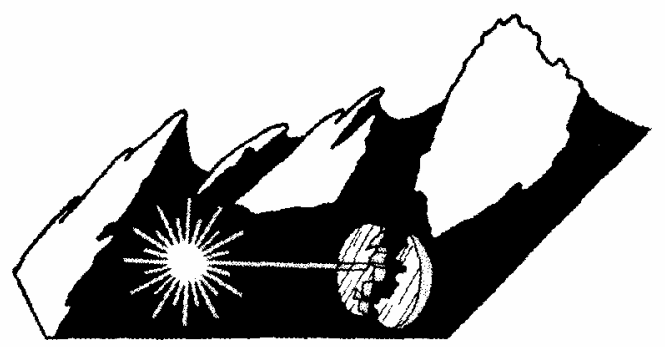

25-27 September 2006

Boulder, Colorado

Editors

Gregory J. Exarhos, Arthur H. Guenther, Keith L. Lewis

Detlev Ristau, M. J. Soileau, Christopher J. Stolz

Organized by

SPIE_-The International Society for Optical Engineering

Cosponsored by

Lawrence Livermore National Laboratory (USA)

Pacific Northwest National Laboratory (USA)

Cooperating Organizations

Center for High Technology Materials at the University of New Mexico (USA) Laser Zentrum Hannover e.V (Germany)

National Institute of Standards and Technology (USA)

Electro-Magnetic Remote Sensing Defence Technology Centre (United Kingdom) College of Optics and Photonics, CREOL \& FPCE, University of Central Florida (USA)

Published by

SPIE_-The International Society for Optical Engineering

Proceedings of SPIE Volume 6403 
The papers included in this volume were part of the technical conference cited on the cover and title page. Papers were selected and subject to review by the editors and conference program committee. Some conference presentations may not be available for publication. The papers published in these proceedings reflect the work and thoughts of the authors and are published herein as submitted. The publisher is not responsible for the validity of the information or for any outcomes resulting from reliance thereon.

Please use the following format to cite material from this book:

Author(s), "Title of Paper," in Laser-Induced Damage in Optical Materials: 2006, edited by Gregory J. Exarhos, Arthur H. Guenther, Keith L. Lewis, Detlev Ristau, M. J. Soileau, Christopher J. Stolz, Proceedings of SPIE Vol. 6403 (SPIE, Bellingham, WA, 2007) Article CID Number.

ISSN 0277-786X

ISBN 9780819465016

Published by

SPIE-The International Society for Optical Engineering

P.O. Box 10, Bellingham, Washington 98227-0010 USA

Telephone 1 360/676-3290 (Pacific Time) · Fax 1 360/647-1445

http://www.spie.org

Copyright (C) 2007, The Society of Photo-Optical Instrumentation Engineers

Copying of material in this book for internal or personal use, or for the internal or personal use of specific clients, beyond the fair use provisions granted by the U.S. Copyright Law is authorized by SPIE subject to payment of copying fees. The Transactional Reporting Service base fee for this volume is $\$ 18.00$ per article (or portion thereof), which should be paid directly to the Copyright Clearance Center (CCC), 222 Rosewood Drive, Danvers, MA 01923. Payment may also be made electronically through CCC Online at http:/ / www.copyright.com. Other copying for republication, resale, advertising or promotion, or any form of systematic or multiple reproduction of any material in this book is prohibited except with permission in writing from the publisher. The CCC fee code is $0277-786 \mathrm{X} / 07 / \$ 15.00$

Printed in the United States of America. 


\title{
Contents
}

\author{
xi Forward \\ G. J. Exarhos, A. H. Guenther, K. L. Lewis, D. Ristau, M. J. Soileau, C. J. Stolz \\ xiii International Program Committee \\ $\mathrm{xv} \quad$ Symposium Welcome \\ G. J. Exarhos \\ xvii Summary of Meeting \\ C. J. Stolz
}

\section{FUNDAMENTAL MECHANISMS}

640302 Femtosecond interaction processes near threshold: damage and ablation (Invited Paper) [6403-01]

R. Fedosejevs, S. E. Kirkwood, R. Holenstein, N. Young, Y. Y. Tsui, Univ. of Alberta (Canada)

640303 Fabrication of the refractive index gratings in optical glasses by filamentary propagation of femtosecond laser pulses [6403-16]

E. Gaižauskas, V. Kudriašov, V. Vaičaitis, V. Sirutkaitis, Vilnius Univ. (Lithuania)

640304 Laser damage on diffractive optics [6403-17]

L. Gallais, G. Demesy, M. Commandré, Institut Fresnel, UMR 6133, Ecole Centrale Marseille, Univ. de Provence-Univ. Paul Cézanne (France); S. Tisserand, S. Gauthier, F. Reversat, M. Hubert, Silios Technologies (France)

Pagination: Proceedings of SPIE follow an e-First publication model, with papers published first online and then in print and on CD-ROM. Papers are published as they are submitted and meet publication criteria. A unique, consistent, permanent citation identifier (CID) number is assigned to each article at the time of the first publication. Utilization of CIDs allows articles to be fully citable as soon they are published online, and connects the same identifier to all online, print, and electronic versions of the publication.

SPIE uses a six-digit CID article numbering system in which:

- The first four digits correspond to the SPIE volume number.

- The last two digits indicate publication order within the volume using a Base 36 numbering system employing both numerals and letters. These two-number sets start with $00,01,02,03,04,05,06,07,08,09,0 \mathrm{~A}, 0 \mathrm{~B} \ldots \mathrm{OZ}$, followed by 10-1Z, 20-2Z, etc.

The CID number appears on each page of the manuscript. The complete citation is used on the first page, and an abbreviated version on subsequent pages. 
640305 Limits of performance: CW laser damage [6403-02]

R. S. Shah, J. J. Rey, A. F. Stewart, The Boeing Co. (USA)

640306 Thermal imaging investigation of modified fused silica at surface damage sites for understanding the underlying mechanisms of damage growth [6403-03]

R. A. Negres, M. W. Burke, P. DeMange, S. B. Sutton, M. D. Feit, S. G. Demos, Lawrence Livermore National Lab. (USA)

640307 Revisited thermal approach to model laser-induced damage and conditioning process in $\mathbf{K H}_{2} \mathbf{P O}_{4}$ and $\mathbf{D}_{2 \times} \mathbf{K H}_{2(1-x)} \mathbf{P O}_{4}$ crystals [6403-15]

A. Dyan, M. Pommiès, G. Duchateau, F. Enguehard, S. Lallich, B. Bertussi, D. Damiani, H. Piombini, H. Mathis, CEA-Le Ripault (France)

640308 Figures of merit for high-energy laser-window materials: thermal lensing and thermal stresses [6403-06]

C. A. Klein, c.a.k. analytics (USA)

64030A Importance of free surfaces for damage crater formation [6403-08]

M. D. Feit, A. M. Rubenchik, Lawrence Livermore National Lab. (USA)

64030C Damages to optical silica glass: processes and mechanisms [6403-04]

S.-N. Luo, Los Alamos National Lab. (USA); L. Zheng, Univ. of Missouri, Columbia (USA); Q. An, H.-A. Wu, Univ. of Science and Technology of China (China); K. Xia, Univ. of Toronto (Canada); S. Ni, Univ. of Science and Technology of China (China)

\section{SURFACES, MIRRORS, AND CONTAMINATION}

64030D Using gold nanoparticles as artificial defects in thin films: What have we learned about laser-induced damage driven by localized absorbers? (Invited Paper) [6403-09]

S. Papernov, A. W. Schmid, Univ. of Rochester (USA)

64030E Study of the evolution of mechanical defects on silica samples under laser irradiation at $355 \mathrm{~nm}[6403-12]$

M. A. Josse, H. Bercegol, R. Courchinoux, T. Donval, L. Lamaignère, B. Pussacq, J. L. Rullier, CEA/CESTA (France)

64030F Numerical and experimental study of focal spot degragation induced by particles on surface optics [6403-18]

B. Martinez, V. Beau, S. Chico, S. Mainguy, J. L. Rullier, CEA/CESTA (France)

64030G Influence of artificial metallic defects size on the surface cleaning process [6403-19] J. Capoulade, J. Y. Natoli, Institut Fresnel, CNRS 6133, Univ. de Provence (France) and Univ. Paul Cézanne (France); S. Palmier, J. L. Rullier, I. Tovena, CEA/DAM/CESTA (France)

$64030 \mathrm{H}$ Effects of laser-induced damage on optical windows in the presence of adhesives under simulated thermal-vacuum conditions [6403-20]

C. Y. Sheng, Genesis Engineering Solutions (USA) 
64030I Impact of organic contamination on 1064-nm laser-induced damage threshold of dielectric mirrors [6403-23]

A. Pereira, J.-G. Coutard, S. Becker, CEA-GRE/DRT/LITEN/DTNM (France); I. Tovena, CEA-CESTA/DAM/DLP (France); P. Bouchut, G. Ravel, CEA-GRE/DRT/LITEN/DTNM (France)

64030J Laser-induced contamination of silica coatings in vacuum [6403-24]

S. Becker, A. Pereira, P. Bouchut, F. Geffraye, C. Anglade, CEA/LITEN/DTNM/LTS (France)

64030K The effect of laser pulse duration on laser-induced damage in $\mathrm{KDP}$ and $\mathrm{SiO}_{2}$ [6403-26]

C. W. Carr, M. J. Matthews, J. D. Bude, M. L. Spaeth, Lawrence Livermore National Lab. (USA)

64030L Growth of laser damage on the input surface of $\mathrm{SiO}_{2}$ at $351 \mathrm{~nm}$ [6403-11]

M. A. Norton, E. E. Donohue, M. D. Feit, R. P. Hackel, W. G. Hollingsworth, A. M. Rubenchik, M. L. Spaeth, Lawrence Livermore National Lab. (USA)

64030M Mitigation of growth of laser initiated surface damage in fused silica using a 4.6- $\mu \mathrm{m}$ wavelength laser (Best Poster Presentation) [6403-27]

G. Guss, I. Bass, V. Draggoo, R. Hackel, S. Payne, Lawrence Livermore National Lab. (USA);

M. Lancaster, P. Mak, Naval Research Lab. (USA)

64030N MRF applications: on the road to making large-aperture ultraviolet laser resistant continuous phase plates for high-power lasers [6403-29]

J. A. Menapace, P. J. Davis, W. A. Steele, Univ. of California, Lawrence Livermore National Lab.

(USA); M. R. Hachkowski, A. Nelson, K. Xin, Zygo Corp. (USA)

64030O Evaluation of cleaning methods for multilayer diffraction gratings [6403-21]

B. Ashe, K. L. Marshall, C. Giacofei, A. L. Rigatti, T. J. Kessler, A. W. Schmid, J. B. Oliver,

J. Keck, A. Kozlov, Univ. of Rochester (USA)

64030P Investigations of sacrificial and plasma mirrors on the HELEN laser CPA beam [6403-10]

J. E. Andrew, A. J. Comley, AWE plc (United Kingdom)

64030Q Surface damage growth mitigation on KDP/DKDP optics using single-crystal diamond micro-machining ball end mill contouring [6403-25]

P. Geraghty, W. Carr, V. Draggoo, R. Hackel, C. Mailhiot, M. Norton, Univ. of California, Lawrence Livermore National Lab. (USA)

\section{MINI-SYMPOSIUM ON OPTICS IN A HOSTILE ENVIRONMENT}

64030S Optical coatings and surfaces in space: MISSE [6403-31]

A. F. Stewart, The Boeing Co. (USA); M. Finckenor, NASA Marshall Space Flight Ctr. (USA)

64030T Laser qualification testing of space optics [6403-53]

P. Allenspacher, W. Riede, German Aerospace Ctr. (Germany); D. Wernham, European Space

Agency/ESTEC (Netherlands) 
64030U Damage threshold investigations of high-power laser optics under atmospheric and vacuum conditions [6403-54]

L. Jensen, M. Jupé, H. Mädebach, H. Ehlers, K. Starke, D. Ristau, Laser Zentrum Hannover e.V.

(Germany); W. Riede, P. Allenspacher, H. Schroeder, German Aerospace Ctr. (Germany)

64030V Surface particulate contamination of the LIL optical components and their evolution under laser irradiation [6403-32]

S. Palmier, S. Garcia, L. Lamaignère, M. Loiseau, T. Donval, J. L. Rullier, I. Tovena, CEA/CESTA (France); L. Servant, Lab. de Physico Chimie Moléculaire, Univ. de Bordeaux I

(France)

64030W Ophthalmic optical coatings: The real world can be more aggressive than you think [6403-34]

M. Mildebrath, Essilor (USA); K. Klemm, Ocean Optics (USA)

64030X A mechanism for erosion of optics exposed to a laser-generated EUV plasma [6403-35]

J. W. Arenberg, S. McNaught, M. Michaelian, H. Shields, D. Moyer, S. Fornaca, F. Martos,

Northrop Grumman Space Technology (USA)

64030Y Xtreme optics: the behavior of cavity optics for the Jefferson Lab Free-Electron Laser [6403-36]

M. Shinn, Thomas Jefferson National Accelerator Facility (USA); C. Behre, Naval Surface

Warfare Ctr. (USA); S. Benson, D. Douglas, F. Dylla, C. Gould, J. Gubeli, D. Hardy, K. Jordan, G. Neil, S. Zhang, Thomas Jefferson National Accelerator Facility (USA)

\section{THIN FILMS}

640310 Magnetron-sputtered nanolaminate and superlattice coatings (Invited Paper) [6403-38] P. M. Martin, L. C. Olsen, W. D. Bennett, C. H. Henager, Pacific Northwest National Lab. (USA)

640311 Laser-induced damage in gradual index layers and Rugate filters [6403-39] M. Jupé, M. Lappschies, L. Jensen, K. Starke, D. Ristau, Laser Zentrum Hannover e.V. (Germany)

640312 Glancing angle deposited thin films and their applications in laser systems [6403-40] J. Shao, S. Wang, Z. Shen, X. Fu, H. He, Z. Fan, Shanghai Institute of Optics and Fine Mechanics (China)

640314 Assessing the impact of atomic oxygen in the damage threshold and stress of Hafnia films grown by ion beam sputter deposition [6403-46]

D. Patel, Y. Wang, M. Larotonda, J. Lovewell, J. Jensen, K. J. Hsiao, E. Krous, J. J. Rocca, C. S. Menoni, Colorado State Univ. (USA); F. Tomasel, Advanced Energy Inc. (USA) and Colorado State Univ. (USA); S. Kholi, P. McCurdy, Colorado State Univ. (USA)

640315 The microstructure and LIDT of $\mathbf{N b}_{2} \mathbf{O}_{5}$ and $\mathbf{T a}_{2} \mathbf{O}_{5}$ optical coatings [6403-50] G. Abromavicius, R. Buzelis, R. Drazdys, Institute of Physics (Lithuania); A. Melninkaitis, D. Miksys, V. Sirutkaitis, Vilnius Univ. (Lithuania); A. Skrebutenas, Optida Co. (Lithuania); R. Juskenas, A. Selskis, Institute of Chemistry (Lithuania) 
640316 Study of laser-induced damage at 2 microns on coated and uncoated $\mathrm{ZnSe}$ substrates [6403-42]

H. Krol, Institut Fresnel, CNRS 6133 (France) and CILAS Marseille (France); C. Grèzes-Besset, CILAS Marseille (France); L. Gallais, J.-Y. Natoli, M. Commandré, Institut Fresnel, CNRS 6133 (France)

640317 Direct measurements of residual absorption in fluoridic thin films and optical materials for DUV laser applications [6403-43]

Ch. Mühlig, W. Triebel, S. Kufert, Ch. Noppeney, Institut für Physikalische Hochtechnologie (Germany); H. Bernitzki, Jenoptik Laser, Optik, Systeme GmbH (Germany)

640318 Laser resistivity of selected multilayer designs for DUV/VUV applications [6403-49] St. Günster, H. Blaschke, D. Ristau, Laser Zentrum Hannover (Germany)

640319 Morphology investigations of laser-induced damage [6403-48]

B. Wu, U. Bartch, Hochschule für Angewandte Wissenschaft und Kunst (Germany); M. Jupé, L. Jensen, M. Lappschies, K. Starke, D. Ristau, Laser Zentrum Hannover e.V. (Germany)

64031A Improvement in laser irradiation resistance of fs-dielectric optics using silica mixtures [6403-47]

M. Jupé, M. Lappschies, L. Jensen, K. Starke, D. Ristau, Laser Zentrum Hannover e.V.

(Germany)

64031B Multilayer dielectric gratings for ultrashort pulse compressor [6403-44]

Y. Dai, Shanghai Institute of Laser and Plasma (China); S. Liu, H. He, J. Shao, K. Yi, Z. Fan, Shanghai Institute of Optics and Fine Mechanics (China)

64031C Optical characterization of anti reflective sol-gel coatings fabricated using dip coating method [6403-51]

A. Melninkaitis, K. Juškevičius, M. Maciulevičius, V. Sirutkaitis, A. Beganskienė, I. Kazadojev, A. Kareiva, Vilnius Univ. (Lithuania); D. Perednis, Institute of Physics (Lithuania)

\section{MATERIALS AND MEASUREMENTS}

64031D Optical characterization in laser damage studies (Best Oral Presentation) (Invited Paper) [6403-62]

M. Commandré, J. Y. Natoli, L. Gallais, F. Wagner, C. Amra, Institut Fresnel, CNRS 6133

(France), Univ. Paul Cézanne (France), and Univ. de Provence (France)

64031E Blackbody thermoluminescence: the missing link to laser-induced damage in silica [6403-63]

P. Bouchut, CEA-GRE/DRT/LITEN/DTNM (France); F. Milesi, CEA-GRE/DRT/LETI/

DPTS (France); C. Da Maren, J.-G. Coutard, CEA-GRE/DRT/LITEN/DTNM (France)

64031F Measuring part per million thin film absorption during deposition [6403-65]

G. Dubé, MetaStable Instruments, Inc. (USA); A. J. Braundmeier, Jr., Southern Illinois Univ. Edwardsville (USA); S. Chelli, Deposition Research Lab., Inc. (USA); R. Juhala, A. Webb, MetaStable Instruments, Inc. (USA) 
64031G Carbon-based coatings for thermal detectors: laser damage and thermal efficiency [6403-74]

K. Ramadurai, Univ. of Colorado (USA); L. Lewis, C. Cromer, National Institute of Standards and Technology (USA); R. L. Mahajan, Virginia Polytechnic Institute and State Univ. (USA); K. E. Hurst, J. H. Lehman, National Institute of Standards and Technology (USA)

$64031 \mathrm{H}$ Measurement of low-absorption optics by thermal imaging [6403-86]

A. F. Stewart, Boeing Directed Energy Systems (USA); W. Hughes, Lockheed Martin Missiles and Space (USA)

64031J Characterization of absorption losses in deep UV optical materials [6403-79]

K. Mann, U. Leinhos, B. Schäfer, Laser-Lab. Göttingen e.V. (Germany)

64031K In situ observation of UV-laser-induced deposit formation by fluorescence measurement [6403-64]

H. Schröder, W. Riede, German Aerospace Ctr. (Germany); E. Reinhold, D. Wernham, Y. Lien, ESA/ESTEC (Netherlands); H. Kheyrandish, CSMA-MATS (United Kingdom)

64031L Characterization of thin films and bulk materials for DUV optical components [6403-73] S. Schröder, M. Kamprath, A. Duparré, Fraunhofer-Institut für Angewandte Optik und Feinmechanik (Germany)

$64031 \mathrm{M}$ Results of sub-nanosecond laser-conditioning of $\mathbf{K D}_{2} \mathbf{P O}_{4}$ crystals [6403-66]

J. J. Adams, J. A. Jarboe, C. W. Carr, M. D. Feit, R. P. Hackel, J. M. Halpin, J. Honig, L. A. Lane, R. L. Luthi, J. E. Peterson, D. L. Ravizza, F. Ravizza, A. M. Rubenchik, W. D. Sell, J. L. Vickers, T. L. Weiland, T. J. Wennberg, D. A. Willard, M. F. Yeoman, Lawrence Livermore National Lab. (USA)

64031N Laser conditioning of KDP crystals using excimer and Nd:YAG lasers [6403-67] B. Bertussi, D. Damiani, M. Pommies, A. Dyan, H. Piombini, X. Leborgne, CEA Le Ripault (France); A. During, L. Lamaignere, G. Gaborit, M. Loiseau, S. Mardelle, T. Donval, CEA/ CESTA (France)

64031P Impurities detection by optical techniques in $\mathbf{K H}_{2} \mathbf{P O}_{4}$ crystals [6403-55] M. Pommiès, D. Damiani, X. Le Borgne, A. Surmin, J.-C. Birolleau, F. Pilon, CEA Le Ripault (France); C. Dujardin, Univ.de Lyon I, Lab. de Physico-Chimie des Matréiaux Luminescents, CNRS (France); B. Bertussi, H. Piombini, CEA Le Ripault (France)

64031Q Characterization tools for KDP/DKDP crystals investigation: toward the identification of laser-damage precursors: Part A. Structural characteristics of rapidly grown crystals [6403-56]

A. Surmin, F. Guillet, S. Lambert, F. Pilon, J.-C. Birolleau, M. Pommies, D. Damiani, B. Bertussi, H. Piombini, X. Leborgne, CEA Le Ripault (France)

64031R Influence of the laser beam size on laser-induced damage in $\mathbf{K H}_{2} \mathbf{P O}_{4}$ [6403-57]

J. Capoulade, J. Y. Natoli, Institut Fresnel, CNRS 6133, Univ. de Provence (France) and Univ.

Paul Cézanne (France); B. Bertussi, M. Pommies, A. Dyan, D. Damiani, H. Piombini, CEA Le Ripault (France) 
64031S An expedited approach to evaluate the importance of different crystal growth parameters on laser damage performance in KDP and DKDP [6403-58]

R. A. Negres, N. P. Zaitseva, P. DeMange, S. G. Demos, Lawrence Livermore National Lab. (USA)

$64031 \mathrm{U}$ The effect of pulse duration on laser-induced damage by 1053-nm light in potassium dihydrogen phosphate crystals [6403-60]

D. A. Cross, Univ. of California, Lawrence Livermore National Lab. (USA) and Central

Washington Univ. (USA); M. R. Braunstein, Central Washington Univ. (USA); C. W. Carr, Univ. of California, Lawrence Livermore National Lab. (USA)

64031V Characterization of KDP crystals used in large aperture doublers and triplers [6403-61] M. Barkauskas, A. Melninkaitis, D. Mikšys, L. Meslinaite, R. Grigonis, V. Sirutkaitis, Vilnius Univ. (Lithuania); H. Bercegol, L. Lamaignère, CEA-Ctr. d'Etudes Scientifiques et Techniques d'Aquitaine (France)

64031W Laser damage investigation in $\mathrm{RbTiOPO}_{4}$ crystals: a study on the anisotropy of the laser induced damage threshold [6403-77]

A. Hildenbrand, F. Wagner, J.-Y. Natoli, M. Commandre, Institut Fresnel, CNRS 6133, Univ. Paul Cézanne Aix-Marseille III (France) and Univ. de Provence Aix-Marseille I (France); H. Albrecht, F. Theodore, Cristal Laser (France)

64031X Laser-induced bulk damage in Yb:S-FAP crystals [6403-80]

Z. M. Liao, J. J. Adams, J. Jarboe, J. Menapace, N. Nielsen, S. Schrauth, J. Wolfe, A. Erlandson, K. Schaffers, C. Stolz, A. Bayramian, J. Carid, Lawrence Livermore National Lab. (USA)

64031Y Characterization of the mid-infrared nonlinear crystals $\mathrm{LiInSe}_{2}$ and $\mathrm{LiInS}_{2}$ in the IR range [6403-81]

O. Balachninaite, L. Petraviciute, M. Maciulevicius, V. Sirutkaitis, Vilnius Univ. (Lithuania); L. Isaenko, S. Lobanov, A. Yelisseyev, Institute of Mineralogy and Petrography (Russia);

J.-J. Zondy, Institut National de Métrologie Conservatoire National des Arts et Métiers (France)

640320 The mechanism of ionization radiation-induced compaction in fused silica [6403-70] F. Piao, KLA-Tencor Corp. (USA); W. G. Oldham, Univ. of California, Berkeley (USA)

640321 Nanosecond laser-induced breakdown in pure and $\mathbf{Y b}^{3+}$-doped fused silica [6403-71] A. V. Smith, B. Do, Sandia National Labs. (USA); M. Soderlund, Liekki Corp. (Finland)

640322 Photochemical adhesion of fused silica optical elements with no adhesive strain [6403-72] M. Murahara, T. Funatsu, Tokyo Institute of Technology (Japan); Y. Okamoto, Okamoto Optic Co. (Japan)

640323 Mitigation of laser damage on fused silica surfaces with a variable profile CO2 laser beam [6403-83]

A. During, CEA/CESTA (France); P. Bouchut, J.-G. Coutard, CEA/LITEN (France);

C. Leymarie, H. Bercegol, CEA/CESTA (France)

640324 Refractive microlens structures with high-damage thresholds enable flexible beam shaping of high-power lasers [6403-75]

O. Homburg, L. Aschke, V. Lissotschenko, LIMO-Lissotschenko Mikrooptik GmbH (Germany) 
640325 Laser-induced damage thresholds of starched PMMA waveplates [6403-85]

A. Melninkaitis, D. Mikšys, M. Maciulevičius, V. Sirutkaitis, Vilnius Univ. (Lithuania); G. Šlekys, Altechna Co. Ltd. (Lithuania); A. V. Samoylov, Astropribor (Ukraine)

640327 A year of automated LDT testing on ion beam sputtered thin film optics and laser conditioning of IBS films [6403-41]

D. C. Ness, T. Bittancourt, A. D. Streater, Research Electro-Optics, Inc. (USA)

640328 Automated laser-damage test system with real-time damage event imaging and detection [6403-88]

J. E. Wolfe, S. E. Schrauth, Lawrence Livermore National Lab. (USA)

640329 Qualification of materials for applications in high fluence lasers [6403-82]

J. A. Pryatel, LRL Energy Services (USA); W. H. Gourdin, G. J. Hampton, D. M. Behne,

R. Meissner, Lawrence Livermore National Lab. (USA)

64032A Materials discovery: informatic strategies for optical materials [6403-89]

K. F. Ferris, B.-J. M. Webb-Robertson, Pacific Northwest National Lab. (USA); D. M. Jones, Proximate Technologies, LLC (USA)

\author{
Abstracts \\ Participant List \\ Author Index
}




\section{Foreword}

This volume contains the papers presented at the $38^{\text {th }}$ Annual Symposium on Optical Materials for High-Power Lasers, held at the National Institute of Standards and Technology in Boulder, Colorado, 25-27 September 2006. The symposium was cosponsored by the Lawrence Livermore National Laboratory (USA) and the Pacific Northwest National Laboratory (USA). Cooperating organizations included the Center for High Technology Materials at the University of New Mexico (USA), Laser Zentrum Hannover e.V. (Germany), the National Institute of Standards and Technology (USA), Electro-Magnetic Remote Sensing Defence Technology Centre (United Kingdom), and the College of Optics, CREOL and FPCE, University of Central Florida (USA). The symposium was attended by 143 participants hailing from Canada, China, India, Israel, Lithuania, France, Germany, Japan, the United States, and the United Kingdom. Almost onethird of the attendees and more than half of the presentations were from abroad. A minisymposium focused on the performance of optics in hostile environments was scheduled for Tuesday morning. All told, 81 papers were presented, including oral and poster presentations plus the mini-symposium.

The meeting offered an opportunity to make many new acquaintances. As usual, the National Institute of Standards and Technology in Boulder, Colorado, offered a setting conducive to interchanges between individuals working in closely related and complementary fields. We look forward to future opportunities at this symposium to discuss the latest advances in understanding the laser damage process. The symposium was divided into four traditional sessions devoted to the following topics: thin films; fundamental mechanisms; materials and measurements; and, surfaces, mirrors and contamination. A mini-symposium on 'Optics in a Hostile Environment' also comprised the meeting. Dr. Gregory J. Exarhos of Pacific Northwest National Laboratory (USA), Dr. Arthur H. Guenther of the Center for High Technology Materials at the University of New Mexico (USA), Dr. Detlev Ristau of the Laser Zentrum Hannover e.V. (Germany), Dr. Christopher J. Stolz of the Lawrence Livermore National Laboratory (USA), Dr. Keith L. Lewis of the Electro-Magnetic Remote Sensing Defence Technology Centre (UK), and Dr. M. J. Soileau, Vice-President of Research at the University of Central Florida (USA) cochaired the symposium.

The editors assume full responsibility for the summary article, which contains a highlighted overview of the symposium. The manuscripts for papers presented at the symposium have been prepared by their authors. Questions pertaining to their content should be addressed to those authors. The interested reader is referred to the bibliography at the end of the summary article for general references to the literature of laser damage studies.

The 39th Annual Symposium of this series will be held in Boulder, Colorado, 24-26 September 2007. A concerted effort will be made to ensure a closer liaison between the high-peak-power and high-average-power laser damage communities, as well as to include damage issues related to multi-institution research efforts and commercial laser applications. Identification of the minisymposium topic is currently underway.

The principal topics to be considered as contributed papers in 2007 do not differ markedly from those enumerated above. We expect to hear more about improved scaling relations as a function of pulse duration in the femtosecond range, area, and wavelength down to the $\mathrm{x}$-ray region, and to see a continuing transfer of information from research activities to industrial practice. New sources at shorter wavelengths continue to be developed, and a corresponding shift in emphasis 
to short-wavelength and repetitively pulsed damage problems is anticipated. Fabrication and test procedures will continue to be developed, particularly in the area of thin films. New materials and the implication of defects on the damage process will undoubtedly be emphasized, as will further reports on conditioning effects and damage repair or mitigation. More papers on highenergy lasers, space-based optics, and nonlinear optical phenomena also are anticipated.

As was initially established in 1992, several distinguished invited speakers will be identified and invited to make presentations of a tutorial or review nature; in addition, late-breaking developments of interest to the attendees will be covered in other contributions.

The purpose of this series of symposia is to exchange information about optical materials for high-power/high-energy lasers. The editors welcome comments and criticism relevant to this purpose from all interested readers.

Gregory J. Exarhos, Pacific Northwest National Laboratory (USA)

Arthur H. Guenther, Center for High Technology Materials at the University of New Mexico (USA)

Keith L. Lewis, Electro-Magnetic Remote Sensing Defence Technology Centre (United Kingdom)

Detlev Ristau, Laser Zentrum Hannover e.V. (Germany)

M. J. Soileau, University of Central Florida (USA)

Christopher J. Stolz, Lawrence Livermore National Laboratory (USA) 


\section{International Program Committee}

The cochairs of this series of symposia rely heavily on an International Program Committee to ensure their awareness of significant research in the broad field of laser-induced damage throughout the world. Its members are also frequently the source of suggestions for invited speakers and mini-symposium topics and leaders. The committee performs a vital service as an outreach for the conference on a global scale. Individuals with suggestions for the meeting are requested to contact any committee member (next page) who is either an acquaintance or in close proximity. The committee is ably led by Keith Lewis, International Program Committee Chair.

Gregory J. Exarhos (greg.exarhos@pnl.gov)

Arthur H. Guenther (agun@chtm.unm.edu)

Keith L. Lewis (klewis@sciovis.com)

Detlev Ristau (dr@lzh.de)

M. J. Soileau (mj@mail.ucf.edu)

Christopher J. Stolz (stolz1@llnl.gov) 


\section{International Program Committee}

Keith L. Lewis, Chair

Electro-Magnetic Remote Sensing Defence

Technology Centre

24 Victoria Rd.

Malvern Worcestershire, WR14 2TE

United Kingdom

Claude Amra

Institut Fresnel ENSPM

CNRS EGIM

Domaine de Saint Jerôme

Marseille Cedex 2013397 France

James E. Andrew

Atomic Weapons Establishment Plc

Bldg C15-1

Aldermaston

Reading Berks RG7 4PR United Kingdom

Hervé Bercagol

CEA-CESTA

BP2

15 ave des Sablieres

Le Barp, 33114 France

Michael D. Feit

Lawrence Livermore National Lab

L-491

7000 East Avenue

Livermore, CA 94550-0808 USA

Jerome B. Franck

AFOSR/NI

110 Duncan Ave., Ste. B-115

Bolling AFB, Washington, DC 20332-0001

USA

Leonid Glebov

CREOL/Univ. of Central Florida

School of Optics

4000 Central Florida Blvd.

Orlando, FL 32816-2700 USA

Klaus Mann

Laser Laboratorium Göttingen e.V.

Hans-Adolf-Krebs-Weg 1

37077 Göttingen Germany
Masataka M. Murahara

Tokai University

Electrical Engineering Department

1117 Kitakaname

Hiratsuka-shi Kanagawa 259-1292 Japan

Semyon Papernov

University of Rochester

Laboratory of Laser Energetics

250 East River Rd.

Rochester, NY 14623-1299 USA

Amy L. Rigatti

University of Rochester

Laboratory for Laser Energetics

250 East River Rd.

Rochester, NY 14632-1299 USA

Detlev Ristau

Laser Zentum Hannover eV

Laser Components Dept

Hollerithallee 8

Hannover, 30419 Germany

Alan Stewart

The Boeing Co.

MC WB-58/L\&EOS

6633 Canoga Ave

Canoga Park, CA 91309-7922 USA

Kunio Yoshida

Osaka Institute of Technology

5-16-1, Ohmiya, Asahi-ku

Osaka 535-8585 Japan 


\title{
Symposium Welcome
}

\author{
On the Occasion of the Thirty-Eighth Boulder Damage Symposium
}

\section{Gregory J. Exarhos}

Pacific Northwest National Laboratory (USA)

The conference cochairs extend a fervent welcome to participants in the $38^{\text {th }}$ Annual Symposium on Optical Materials for High Power Lasers held at the NIST facility in Boulder, Colorado. Significant contributions from the global scientific community continue to both enrich the technical content of the meeting and contribute to its vitality. The international program committee has been instrumental in promoting this conference worldwide, attracting scientists and engineers from more than a dozen different countries. We acknowledge these key contributions in this series of the Proceedings of SPIE that archive significant research results in the laser damage to optical materials field. The Proceedings of SPIE comprises an important resource for collecting the latest results pursuant to laser-induced optical damage, and we gratefully acknowledge the efforts of the authors in both preparing oral and poster presentations and contributing manuscripts to these proceedings.

This symposium is structured so as to promote camaraderie among the participants in a number of ways. All oral talks are presented in one ongoing session for the three-day meeting that not only localizes the attendees to one conference room, but also encourages more extensive participation in the question and answer session following each presentation. A relatively uninhibited audience promotes lively exchanges that probe the scientific content of the talks, often leading to new directions for follow-on research and development. Audience responses are recorded, transcribed, and appear in the proceedings following each oral paper. Six poster sessions, geared to the subject content of the oral presentations, were offered this year, and in the inimitable conference tradition, the presenters were invited to provide a succinct overview of their posters midway through the morning oral sessions. In addition, ample time was provided for viewing the posters and networking among the participants. This approach contributes to the strength of the meeting and, indeed, promotes international exchanges in the laser-damage and related technical communities.

Four subject areas comprise core topics within the symposium. These include: thin films; materials and measurements; fundamental mechanisms; and surfaces, mirrors, and contamination. The last subject area has been modified this year to recognize the critical aspect of optic contamination on laser damage processes. To insure that the meeting is indeed dynamic, a mini-symposium is offered each year in a subject area of current interest to the laser-damage community. This year the focus was on optics in a hostile environment. Key issues in this current technical program that are distributed among the respective topical areas, tend to emphasize shorter wavelength irradiation and ultrashort pulsewidths. Presentations related to these topics are expected to be even more prevalent in subsequent symposia.

The cochairs gratefully acknowledge the untiring efforts of the SPIE staff, Susie McGuire, who also transcribes the recorded question and answer sessions following each oral presentation, and Joan Guenther, conference treasurer. The organizers also acknowledge the efforts of the NIST Staff, Gordon Day, Wendy Ortega, and our technical contact, Kent Rochford, who assist with 
coordinating activities and arranging for audio/video facilities in the NIST auditorium. Financial support for this meeting has been graciously provided by the meeting cosponsors, Lawrence Livermore National Laboratory and Pacific Northwest National Laboratory.

The venue for this annual fall meeting, known to most of us as the Boulder Damage Symposium, continues to be located in this beautiful region of Colorado famous for its close proximity to the mountains and an abundance of hiking trails and other recreational activities. The cochairs welcome you to this meeting and wish you all a most productive and enjoyable visit to Boulder. An invitation to you and your colleagues to participate in the meeting again next year is enthusiastically extended. 


\title{
Summary of Meeting
}

\author{
Laser-Induced Damage in Optical Materials \\ $38^{\text {th }}$ Annual Symposium \\ 25-27 September 2006 \\ Christopher J. Stolz \\ Lawrence Livermore National Laboratory \\ PO Box 808, L-491 \\ Livermore, CA 94551 USA
}

\begin{abstract}
These proceedings contain the papers presented as oral and poster presentations at the $38^{\text {th }}$ Annual Symposium on Optical Materials for High-Power Lasers. The conference was held at the National Institute of Standards and Technology facility in Boulder Colorado on 25-27 September 2006. The symposium was divided into the traditional sessions devoted to the following topics: thin films; surfaces, mirrors and contamination; fundamental mechanisms; materials and measurements; and finally, a mini-symposium on optics in a hostile environment. Dr. Gregory J. Exarhos of Pacific Northwest National Laboratory (USA), Dr. Arthur H. Guenther of the Center for High Technology Materials at the University of New Mexico (USA), Dr. Keith L. Lewis of Electromagnetic Remote Sensing Defence Technology Center (UK), Dr. Detlev Ristau of the Laser Zentrum Hannover e.V. (Germany), Dr. M. J. Soileau, of the University of Central Florida (USA), and Mr. Christopher J. Stolz of the Lawrence Livermore National Laboratory (USA), co-chaired the symposium.
\end{abstract}

All told, 81 papers were presented, including oral and poster presentations plus a minisymposium. No parallel sessions were held, allowing the opportunity to discuss common research interests with all the presenters. With 143 participants attending, the meeting offered an opportunity to make many new acquaintances. Although held annually in the U.S., this is a truly international conference with 35 percent of the attendees and 50 percent of the presentations coming from abroad. As usual, the National Institute of Standards and Technology in Boulder, Colorado, offered a setting conductive to interchanges between individuals working in closely related and complementary fields. We look forward to future opportunities to again come together there.

The 39th Annual Symposium of this series will be held in Boulder, Colorado, 24-26 September 2007. A concerted effort will be made to ensure a close liaison between the high-peak-power and high-average-power communities, as well as to include damage issues related to various research efforts and commercial laser applications. A mini-symposium related to the subject of optic lifetime issues associated with continuous and high repetition rate lasers is anticipated.

The principal topics to be considered as contributed papers in 2007 do not differ drastically from those enumerated above, although given the amount of interest in contamination over the last few years, the surfaces and mirrors session was renamed surfaces, mirrors, and contamination this year. We expect to hear more about the impacts of contamination on the laser resistance of optical components and the impacts of defects since both of these topics continue to generate significant. High-energy laser windows and crystals continue to place limitations on laser 
systems, so remain an active area of research and spirited debate. Refinement of the mitigation strategy consisting of damage initiation followed by arresting damage growth through postprocessing techniques is also expected to be a continued focus for next year, as large-aperture fusion lasers manufacture a large number of laser-resistant UV optics. Short pulse laser optics and damage phenomena remain an active area of research. We also expect to hear more about new measurement techniques to improve our understanding of the different damage mechanisms or to improve the manufacturing of optical materials and thin films for optical components of greater laser damage resistance.

As was initially established in 1992, several distinguished invited speakers will make presentations of a tutorial or review nature. In addition, other contributors will cover late-breaking developments of interest to the attendees.

The purpose of this series of symposia is to exchange information about optical materials for high-power/high-energy lasers. The editors welcome comments and criticism from all interested readers relevant to this purpose.

Key words: laser damage, laser interaction, optical components, optical fabrication, optical materials and properties, thin film coatings, contamination.

\section{Introduction}

The $38^{\text {th }}$ Annual Symposium on Optical Materials for High-Power Lasers (a.k.a. the Boulder Damage Symposium, because of its Boulder, Colorado, venue) was held 25-27 September 2006. This symposium continues to be the principal U.S. and international forum for the exchange of information relative to the interaction of intense laser light with optical media and components. Historically, the meeting has been divided into four broad categories: thin films; fundamental mechanisms; materials and measurements; and surfaces, mirrors, and contamination as illustrated in figure 1.

\section{Thin Films}

Because of the tremendous range of applications of optical multilayers for modifying the optical performance of elements (e.g., reflectivity, wavelength sensitivities, polarization, or simply protection, etc.), this area is receiving considerable attention at the present time. Besides damage thresholds or sensitivity, topics include advanced thin deposition technology, film structure, film design, film response to environmental attack and aging, and numerous reports on important film properties such as adhesion, thermal conductivity, absorption, stability, defect identification, aging - drift and moisture infusion, and conditioning processes to improve performance.

Dense thin film processes offer the benefit of environmental stability; so much of the research in the field of thin films is proceeding in this direction. Laser interaction studies are uncovering areas were dense films offer advantages over traditional e-beam coatings. An example from the invited talk is the use of magnetron sputtering for nanoscale compensationally modulated coatings to create supperlattices and quantum well structures.

Coating defects continue to be an area of active interest in both process optimization, to minimize defect formation, as well as mitigation techniques such as laser conditioning. This year we saw an increase of interest in VUV and XUV coatings. 


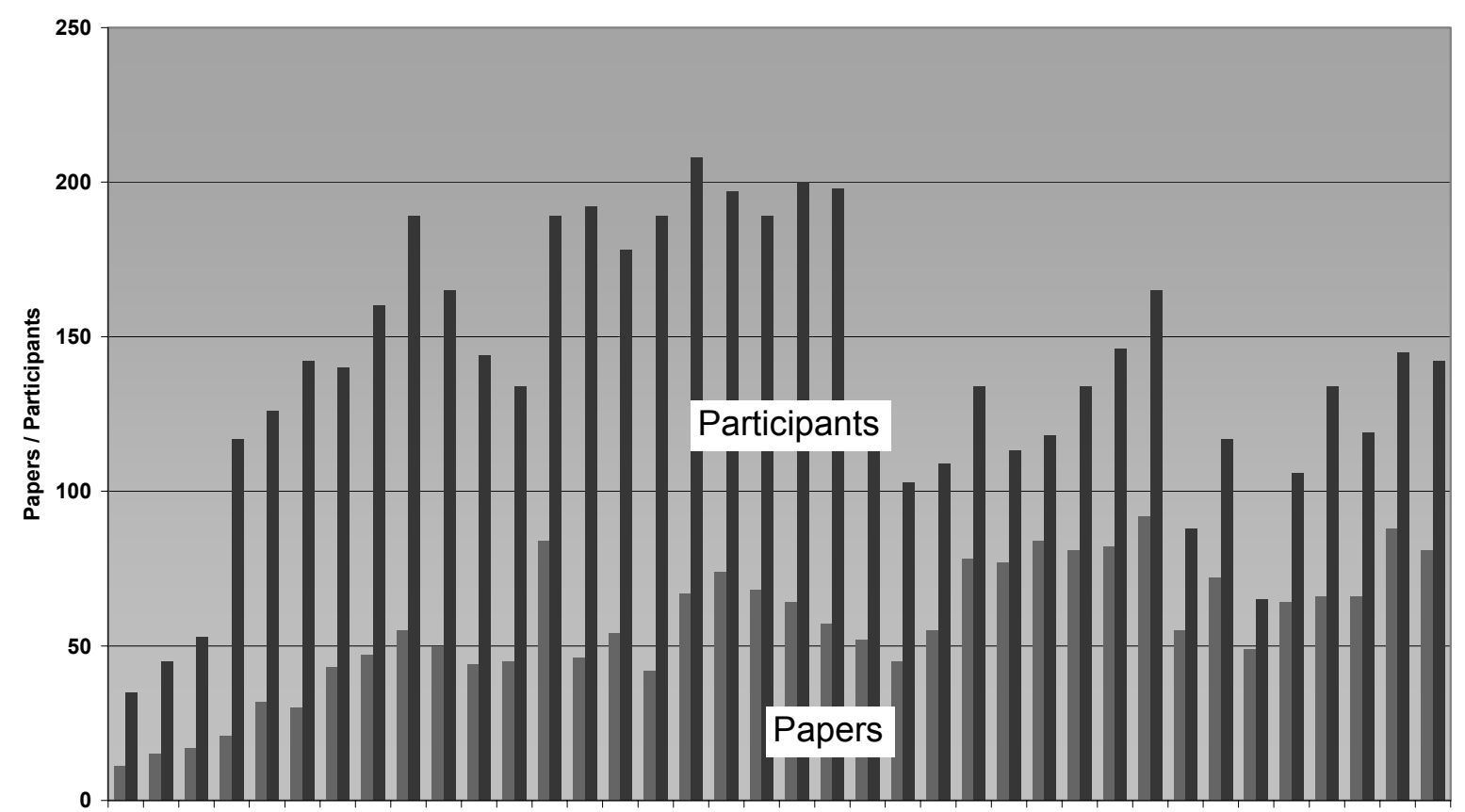

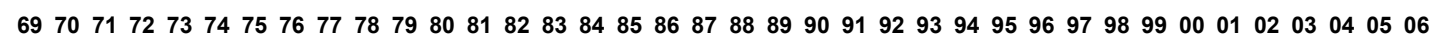
Conference year

Topical emphasis of conference by year

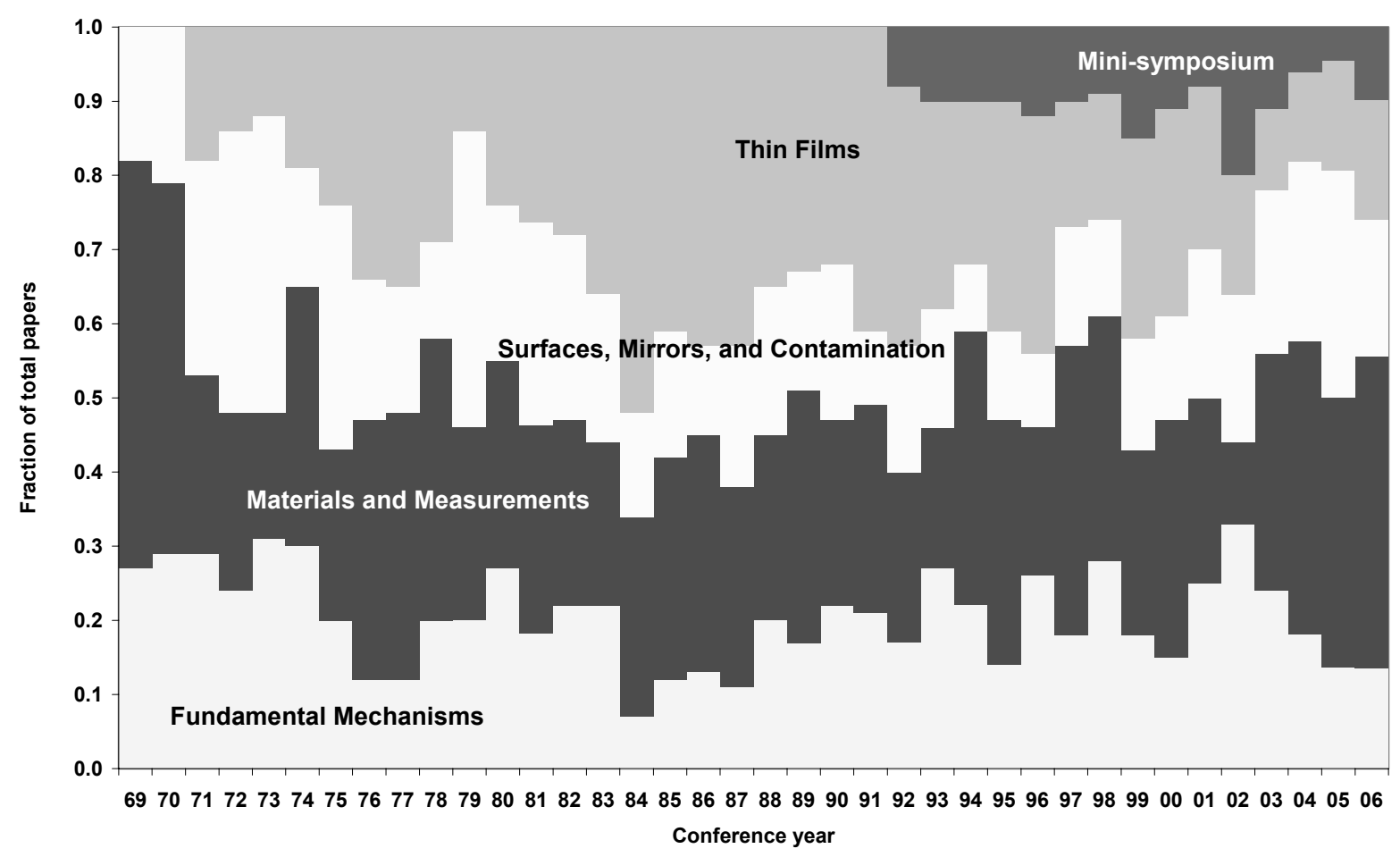

Fig. 1 Historical statistics of conference attendance and paper submission (top) and distribution of submissions by topical area (bottom). 


\section{Fundamental Mechanisms}

This area deals with the interaction of light with matter - where real system experience is presented. Topics include nonlinear behavior, self-focusing, thermal modeling, and experimental data reduction protocols (e.g. effects of pulse width, repetition rate or duty cycle, spot size, wavelength, temperature, ionizing radiation, and other environmental effects), as well as all types of experimental or material variable scaling relationships that not only afford insight into the fundamentals of the interaction process, but allow extrapolations for engineering and costbenefit evaluations. In many areas, these insights are based on real-world, systems-level tests, as opposed to a frequently pristine laboratory environment.

Due to the interest in ultrashort phenomena, the invited speaker for the fundamental mechanisms session spoke on femtosecond interaction processes near threshold: damage and ablation. At ultrashort pulselengths, damage mechanisms are driven by solid state physical processes and material properties. Most of the damage research at long pulses (nanosecond and longer) focuses on sub-micron to micron-scale defects (coating nodules, subsurface cracks, absorbing polishing compounds) and thermo-mechanical damage.

\section{Surfaces and Mirrors}

Here one will find presentations on surface preparation (including single-point diamond micromachining and ductile grinding), subsurface damage characterization, roughness and scattering, environmental degradation and aging, as well as substrate material properties, including cooling techniques, and, of course, damage measurements and the cleaning of surfaces. The crux of the contamination problem is fundamentally that damage experiments done in controlled clean laboratory settings do not necessarily yield the same results as laser operations in less pristine operating environments. There is a significant amount of work needed in understanding what contamination is acceptable, what contamination is threatening to optic survivability, and how fluence-limiting or lifetime-limiting contamination can be eliminated or mitigated from operating laser systems.

There was also a significant amount of continued interest in understanding how nano-cluster absorbing defects fluence limit bare and coated surfaces. This topic was covered by an excellent review paper of the topic.

\section{Materials and Measurements}

This section deals with laser damage to the bulk of transparent optical media - whether amorphous, polymeric, polycrystalline, or crystalline - and its preparation, as well as reports of material properties of import to their optical function and / or the damage process, e.g., linear and nonlinear refractive indices, absorption, thermal conductivity, stress-optic coefficients, moduli, and defects. Also included are new techniques for measuring these quantities, which present a continuing challenge as materials are improved in quality and diversity.

The topic of crystalline materials continues to be an active area of interest due to their attractive nonlinear properties and high efficiency gain media. Specific crystals that are addressed in this proceedings are KDP, CaF $2, \mathrm{Nd}: \mathrm{YAG}, \mathrm{RbTiOPO}_{4}, \mathrm{Yb}: \mathrm{S}-\mathrm{FAP}, \mathrm{LilnSe}_{2}$, and $\mathrm{LilnS}_{2}$; laser materials for both commercial and laboratory-scale lasers. 
A number of measurement papers dealt specifically with damage test systems that are either new facilities, or new methods in addition to the ISO standard. Finally there continues to be interest in absorption and fluorescence measurements to identify precursors of damage initiators. The invited talk summarized extremely well a variety of non-destructive measurement techniques to examine absorption, scattering, and luminescence of defects that impact laser resistance.

\section{Mini-Symposium on Optics in a Hostile Environment}

This year the meeting was concluded with a small mini-symposium dealing with the topic of optics survival in a variety of extreme environments. Of particular interest were the results of the impacts of space environments on a variety of optical samples. Typically during the minisymposium, a paper will be presented that is marginally relevant to the main topic of the meeting, but is an excellent review of the state of a specific technology. This was especially true for the paper on ophthalmic optics which are exposed to extremely hostile environments, although at extremely low photon flux. The mini-symposium was organized this year by Alan Stewart from The Boeing Company (USA).

\section{Invited Papers}

As usual, the 2006 meeting was highlighted by several invited papers. They included:

1. "Femtosecond interaction processes near threshold: damage and ablation," R. Fedosejevs, University of Alberta (Canada).

2. "Using gold nanoparticles as artificial defects in thin films: what have we learned about laserinduced damage driven by localized absorbers?," S. Papernov, University of Rochester (USA).

3. "Recent advances in magnetron sputtered superlattice and quantum well structures," P. M. Martin, Pacific Northwest National Laboratory (USA).

4. "Optical characterization in laser damage studies," M. Commandré, Institut Fresnel (France).

\section{Conference Awards}

Beginning with the meeting in 2000, the organizers instituted a best paper award in the oral and poster categories. The awards appropriately take the form of laser-induced art in an optical glass plaque. (see, e.g., paper by I. N. Trotski, Proc. SPIE 4679, 392-399 (2001) plus a remuneration).

Winners selected for 2006 include, for best oral presentation, "Optical characterization in laser damage studies," M. Commandré, J.Y. Natoli, L. Gallais, F. Wagner, C. Amra, Institut Fresnel (France). The best poster presentation went to "Mitigation of growth of laser initiated surface damage in fused silica using a 4.6- $\mu \mathrm{m}$ wavelength laser," G. Guss, I. Bass, V. Draggoo, R. Hackel, S. Payne, Lawrence Livermore National Laboratory (USA); M. Lancaster, P. Mak, Naval Research Laboratory (USA). 


\section{In Conclusion}

The location in Boulder, Colorado during autumn at the venue of the National Institute of Standards and Technology and its outstanding facilities and support staff, were appreciated by all. The 143 attendees were easily accommodated with ample opportunity to mingle and socialize.

The organizers of the Boulder Damage Symposium look for opportunities to join with other related groups for joint meetings in the future. For example, in 2002 we had a joint meeting with the $7^{\text {th }}$ International Workshop on Laser Beam and Optics Characterization, again with no parallel sessions.

We must also take note of the seamless transition of the administrative functions of the symposium to SPIE. Their presence, experience, resources, and professionalism clearly were made manifest with on-line reservations, payment by credit cards, badges, preparation of the abstract book and pocket programs, and on-line document service, to which we may add the social functions - thanks to them, "A good time was had by all."

\section{Acknowledgments}

A number of volunteers help tirelessly with some of the administrate duties necessary to put on a conference of this magnitude. Joan Guenther continues to handle the residual financial assets of Laser Damage Conference, Inc., because the accountant for our nonprofit corporation resides in New Mexico. Susie McGuire, Administrative Assistant to Greg Exarhos, assists with transcriptions of technical questions asked at the end of each talk. Susie also assisted SPIE staff at the conference with registration, setup, and general questions.

Of course, we are all indebted to Kent Rochford, Division Chief of the Optoelectronics Division, who was the prime contact at NIST, for his continued support and encouragement, and Wendy Ortega, also of NIST, who together made it possible to hold a seamless meeting. On behalf of all the organizers and attendees, we thank them for their tireless efforts.

\section{References}

\section{Books:}

A. J. Glass and A. H. Guenther, eds. Damage in Laser Glass, ASTM Spec. Tech. Pub. 469, ASTM, Philadelphia, PA (1969).

N. Bloembergen, Fundamentals of Damage in Laser Glass, National Materials Advisory Board Publ. NMAB-271, National Academy of Sciences (1970).

N. Bloembergen, High-Power Infrared Laser Windows, National Materials Advisory Board Publ. NMAB-356 (1971).

R. M. Wood, Laser-Induced Damage in Optical Materials, Adam Hilger, Bristol (UK) (1986).

M. J. Weber, ed., Handbook of Laser Science and Technology, Vol. III: Optical Materials, Part 1: Nonlinear Optical Properties/Radiation Damage, CRC, Boca Raton, FL (1986).

M. J. Weber, ed., Handbook of Laser Science and Technology, Vol. IV: Optical Materials, Part 2: Properties, CRC, Boca Raton, FL (1986).

M. J. Weber, ed., Handbook of Laser Science and Technology, Vol. V: Optical Materials, Part 3: Applications, Coatings, and Fabrication, CRC, Boca Raton, FL (1987).

R. M. Wood, Ed., Selected Papers on Laser Damage in Optical Materials, SPIE Milestone Series Vol. MS24, Bellingham, WA (U.S.) (1990). 
M. R. Kozlowski, Damage-Resistant Laser Coatings, in Thin Films for Optical Systems, F. Flory, ed., Marcel Dekker, New York, 521-549 (1995).

M. J. Weber, ed., Handbook of Laser Science and Technology, Suppl. 2, Optical Materials, CRC, Boca Raton, FL, (1995).

A. H. Guenther, ed., International Trends in Applied Optics, SPIE Press monograph, Bellingham, Washington, Chapters 1, 3, 8, 9, 10, \& 12 (2002).

M. J. Weber, ed., Handbook of Optical Materials, CRC, Boca Raton, FL (2002).

R. M. Wood, The Power and Energy-Handling Capability of Optical Material, Components, and Systems, (Tutoriual Texts in Optical Engineering Vol TT60 A. R. Weeks Series Editor SPIE Press Bellingham WA) (2003).

R. M. Wood, Laser Induced Damage of Optical Materials (Institute of Physics Publishing, Bistrol, UK) (2003).

C. J. Stolz and F. Y. Génin, Laser Resistant Coatings, in Optical Interference Coatings, N. Kaiser and H. Pulker, eds., Springer-Verlag, Berlin, 310-333 (2003).

\section{Proceedings:}

A. J. Glass and A. H. Guenther, eds., Damage in Laser Materials, Nat. Bur. Stand. (U.S.) Spec. Publ. 341 (1970).

A. J. Glass and A. H. Guenther, Eds., Damage in Laser Materials: 1971, Nat. Bur. Stand. (U.S.) Spec. Publ. 356 (1971).

A. J. Glass and A. H. Guenther, eds., Laser-Induced Damage in Optical Materials: 1972, Nat. Bur. Stand. (U.S.) Spec. Publ. 372 (1972).

A. J. Glass and A. H. Guenther, Eds., Laser-Induced Damage in Optical Materials: 1973, Nat. Bur. Stand. (U.S.) Spec. Publ. 387 (1973).

A. J. Glass and A. H. Guenther, eds., Laser-Induced Damage in Optical Materials: 1974, Nat. Bur. Stand. (U.S.) Spec. Publ. 414 (1974).

A. J. Glass and A. H. Guenther, eds., Laser-Induced Damage in Optical Materials: 1975, Nat. Bur. Stand. (U.S.) Spec. Publ. 435 (1975).

A. J. Glass and A. H. Guenther, eds., Laser-Induced Damage in Optical Materials: 1976, Nat. Bur. Stand. (U.S.) Spec. Publ. 462 (1976).

A. J. Glass and A. H. Guenther, eds., Laser-Induced Damage in Optical Materials: 1977, Nat. Bur. Stand. (U.S.) Spec. Publ. 509 (1977).

A. J. Glass and A. H. Guenther, eds., Laser-Induced Damage in Optical Materials: 1978, Nat. Bur. Stand. (U.S.) Spec. Publ. 541 (1978).

H. E. Bennett, A. J. Glass, A. H. Guenther, and B. E. Newnam, eds., Laser-Induced Damage in Optical Materials: 1979, Nat. Bur. Stand. (U.S.) Spec. Publ. 568 (1979).

H. E. Bennett, A. J. Glass, A. H. Guenther, and B. E. Newnam, eds., Laser-Induced Damage in Optical Materials: 1980, Nat. Bur. Stand. (U.S.) Spec. Publ. 620 (1981).

H. E. Bennett, A. J. Glass, A. H. Guenther, and B. E. Newnam, eds., Laser-Induced Damage in Optical Materials: 1981, Nat. Bur. Stand. (U.S.) Spec. Publ. 638 (1983).

H. E. Bennett, A. H. Guenther, D. Milam, and B. E. Newnam, eds., Laser-Induced Damage in Optical Materials: 1982, Nat. Bur. Stand. (U.S.) Spec. Publ. 669 (1984).

H. E. Bennett, A. H. Guenther, D. Milam, and B. E. Newnam, eds., Laser-Induced Damage in Optical Materials: 1983, Nat. Bur. Stand. (U.S.) Spec. Publ. 688 (1985).

H. E. Bennett, A. H. Guenther, D. Milam, and B. E. Newnam, eds., Laser-Induced Damage in Optical Materials: 1984, Nat. Bur. Stand. (U.S.) Spec. Publ. 727 (1986).

H. E. Bennett, A. H. Guenther, D. Milam, and B. E. Newnam, eds., Laser-Induced Damage in Optical Materials: 1985, Nat. Bur. Stand. (U.S.) Spec. Publ. 746 (1987). 
H. E. Bennett, A. H. Guenther, D. Milam, and B. E. Newnam, eds., Laser-Induced Damage in Optical Materials: 1986, Nat. Bur. Stand. (U.S.) Spec. Publ. 752 (1987).

H. E. Bennett, A. H. Guenther, D. Milam, B. E. Newnam, and M. J. Soileau, eds., Laser-Induced Damage in Optical Materials: 1987, Nat. Bur. Stand. (U.S.) Spec. Publ. 756 (1988).

H. E. Bennett, A. H. Guenther, B. E. Newnam, and M. J. Soileau, eds., Laser-Induced Damage in Optical Materials: 1988, Nat. Bur. Stand. (U.S.) Spec. Publ. 775 (1989).

H. E. Bennett, L. L. Case, A. H. Guenther, B. E. Newnam, and M. J. Soileau, eds., Laser-Induced Damage in Optical Materials: 1989, NIST (U.S.) Spec. Publ. 801, ASTM STP 1117 and Proc. SPIE 1438 (1989).

H. E. Bennett, L. L. Case, A. H. Guenther, B. E. Newnam, and M. J. Soileau, eds., Laser-Induced Damage in Optical Materials: 1990, ASTM STP 1141 and Proc. SPIE 1441 (1991).

H. E. Bennett, L. L. Case, A. H. Guenther, B. E. Newnam, and M. J. Soileau, eds., Laser-Induced Damage in Optical Materials: 1991, Proc. SPIE 1624 (1992).

H. E. Bennett, L. L. Case, A. H. Guenther, B. E. Newnam, and M. J. Soileau, eds., Laser-Induced Damage in Optical Materials: 1992, Proc. SPIE 1848 (1993).

H. E. Bennett, L. L. Case, A. H. Guenther, B. E. Newnam, and M. J. Soileau, eds., Laser-Induced Damage in Optical Materials: 1993, Proc. SPIE 2114 (1994).

H. E. Bennett, A. H. Guenther, M. R. Kozlowski, B. E. Newnam, and M. J. Soileau, eds., LaserInduced Damage in Optical Materials: 1994, Proc. SPIE 2428 (1995).

H. E. Bennett, A. H. Guenther, M. R. Kozlowski, B. E. Newnam, and M. J. Soileau, eds., LaserInduced Damage in Optical Materials: 1995, Proc. SPIE 2714 (1996).

H. E. Bennett, A. H. Guenther, M. R. Kozlowski, B. E. Newnam, and M. J. Soileau, eds., LaserInduced Damage in Optical Materials: 1996, Proc. SPIE 2966 (1997).

G. J. Exarhos, A. H. Guenther, M. R. Kozlowski, and M. J. Soileau, eds., Laser-Induced Damage in Optical Materials: 1997, Proc. SPIE 3244 (1998).

G. J. Exarhos, A. H. Guenther, M. R. Kozlowski, K. Lewis, and M. J. Soileau, eds., Laser-Induced Damage in Optical Materials: 1998, Proc. SPIE 3578 (1999).

G. J. Exarhos, A. H. Guenther, M. R. Kozlowski, K. Lewis, and M. J. Soileau, eds., Laser-Induced Damage in Optical Materials: 1999, Proc. SPIE 3902 (2000).

G. J. Exarhos, A. H. Guenther, M. R. Kozlowski, K. Lewis, and M. J. Soileau, eds., Laser-Induced Damage in Optical Materials: 2000, Proc. SPIE 4347 (2001).

G. J. Exarhos, A. H. Guenther, K. Lewis, M. J. Soileau, and C. J. Stolz eds., Laser-Induced Damage in Optical Materials: 2001, Proc. SPIE 4679 (2002).

G. J. Exarhos, A. H. Guenther, K. Lewis, N. Kaiser, M. J. Soileau, and C. J. Stolz eds., LaserInduced Damage in Optical Materials: 2002, Proc. SPIE 4932 (2003).

G. J. Exarhos, A. H. Guenther, K. Lewis, N. Kaiser, M. J. Soileau, and C. J. Stolz eds., LaserInduced Damage in Optical Materials: 2003, Proc. SPIE 5273 (2004).

G. J. Exarhos, A. H. Guenther, K. Lewis, N. Kaiser, M. J. Soileau, and C. J. Stolz eds., LaserInduced Damage in Optical Materials: 2004, Proc. SPIE 5647 (2005).

G. J. Exarhos, A. H. Guenther, K. Lewis, N. Kaiser, M. J. Soileau, and C. J. Stolz eds., LaserInduced Damage in Optical Materials: 2005, Proc. SPIE 5991 (2006).

\section{Compact Discs:}

A. H. Guenther, ed., Laser-Induced Damage in Optical Materials: Collected papers 1969-1998 (a three CD-ROM set available from SPIE, P.O. Box 10, Bellingham, WA 98227-0010) (1999).

A. H. Guenther, ed., Laser-Induced Damage in Optical Materials: Collected papers 1999-2003

(CD-ROM available from SPIE, P.O. Box 10, Bellingham, WA 98227-0010) (2004). 


\section{Journal articles:}

A. J. Glass and A. H. Guenther, eds., Laser-Induced Damage in Optical Materials: A conference Report, Appl. Opt. 13 (1): 74-88 (1974).

A. J. Glass and A. H. Guenther, eds., Laser-Induced Damage in Optical Materials: $6^{\text {th }}$ ASTM Symposium, Appl. Opt. 14 (3): 698-715 (1975).

A. J. Glass and A. H. Guenther, eds., Laser-Induced Damage in Optical Materials: $7^{\text {th }}$ ASTM Symposium, Appl. Opt. 15 (6): 1510-1529 (1976).

A. J. Glass and A. H. Guenther, eds., Laser-Induced Damage in Optical Materials:87th ASTM Symposium, Appl. Opt. 16 (5): 1214-1231 (1977).

A. J. Glass and A. H. Guenther, eds., Laser-Induced Damage in Optical Materials: 9th ASTM Symposium, Appl. Opt. 17 (6): 2386-2411 (1978).

A. J. Glass and A. H. Guenther, eds., Laser-Induced Damage in Optical Materials: $10^{\text {th }}$ ASTM Symposium, Appl. Opt. 18 (13): 2212-2229 (1979).

H. E. Bennett, A. J. Glass, A. H. Guenther, and B. E. Newnam, eds., Laser-Induced Damage in Optical Materials: 11th ASTM Symposium, Appl. Opt. 19 (14): 2375-2397 (1980).

H. E. Bennett, A. J. Glass, A. H. Guenther, and B. E. Newnam, eds., Laser-Induced Damage in Optical Materials: 12th ASTM Symposium, Appl. Opt. 20 (17): 3003-3019 (1981).

H. E. Bennett, A. H. Guenther, D. Milam, and B. E. Newnam, eds., Laser-Induced Damage in Optical Materials: 13 th ASTM Symposium, Appl. Opt. 22 (20): 3276-3296 (1983).

H. E. Bennett, A. H. Guenther, D. Milam, and B. E. Newnam, eds., Laser-Induced Damage in Optical Materials: 14th ASTM Symposium, Appl. Opt. 23 (21): 3782-3795 (1984).

H. E. Bennett, A. H. Guenther, D. Milam, and B. E. Newnam, eds., Laser-Induced Damage in Optical Materials: 15th ASTM Symposium, Appl. Opt. 25 (2): 258-275 (1986).

H. E. Bennett, A. H. Guenther, D. Milam, and B. E. Newnam, eds., Laser-Induced Damage in Optical Materials: 16 th ASTM Symposium, Appl. Opt. 26 (5): 813-827 (1987).

A. H. Guenther, "Optics damage constrains laser design and performance," Laser Focus World, 29, 83-87, 1992.

A. H. Guenther, "Previewing the Boulder Damage Symposium," Lasers and Optronics 12, 2526,1993.

A. H. Guenther, "Laser-Induced Damage in Optical Materials at the October 6-8, 1997 Symposium on Optical Materials for High-Power Lasers (Boulder Damage Symposium), Boulder, Colorado" J. Laser Appl. 9, 261-266, 1997. 
Downloaded From: https://www.spiedigitallibrary.org/conference-proceedings-of-spie on 26 Apr 2023

Terms of Use: https://www.spiedigitallibrary.org/terms-of-use 